\title{
Genomic insights into the versatility of the plant growth-promoting bacterium Azospirillum amazonense
}

\author{
Fernando H Sant'Anna', Luiz GP Almeida², Ricardo Cecagno', Luciano A Reolon', Franciele M Siqueira', \\ Maicon RS Machado', Ana TR Vasconcelos ${ }^{2}$ and Irene S Schrank ${ }^{1,3^{*}}$
}

\begin{abstract}
Background: The species Azospirillum amazonense belongs to a well-known genus of plant growth-promoting bacteria. This bacterium is found in association with several crops of economic importance; however, there is a lack of information on its physiology. In this work, we present a comprehensive analysis of the genomic features of this species.

Results: Genes of A. amazonense related to nitrogen/carbon metabolism, energy production, phytohormone production, transport, quorum sensing, antibiotic resistance, chemotaxis/motility and bacteriophytochrome biosynthesis were identified. Noteworthy genes were the nitrogen fixation genes and the nitrilase gene, which could be directly implicated in plant growth promotion, and the carbon fixation genes, which had previously been poorly investigated in this genus. One important finding was that some A. amazonense genes, like the nitrogenase genes and RubisCO genes, were closer phylogenetically to Rhizobiales members than to species of its own order.

Conclusion: The species A. amazonense presents a versatile repertoire of genes crucial for its plant-associated lifestyle.
\end{abstract}

\section{Background}

The genus Azospirillum ( $\alpha$-proteobacteria class) encompasses free-living bacteria that can improve the growth of many economically important plants, mainly cereals (for an extensive review, see [1]). Therefore, these microorganisms are considered as plant growth-promoting rhizobacteria (PGPR). Species of this genus are widely distributed in nature, living in soils of tropical, subtropical and temperate regions all over the world. Several aspects of their physiology seem to be related to a plant stimulatory effect, notably their ability to synthesize phytohormones. Although these microorganisms are able to fix atmospheric nitrogen, the exact contribution of this process to plant growth is still disputable [1-3].

So far, fifteen species of the Azospirillum genus have been described ([4] and references therein). However,

\footnotetext{
* Correspondence: irene@cbiot.ufrgs.br

'Centro de Biotecnologia, Universidade Federal do Rio Grande do Sul, Av.

Bento Gonçalves, 9500, Campus do Vale, Porto Alegre, RS, Brazil

Full list of author information is available at the end of the article
}

most research efforts have been dedicated to the species Azospirillum brasilense, neglecting the potential offered by the biological diversity of this genus.

The bacterium A. amazonense, the focus species of this study, was initially isolated from forage grasses grown in the Amazon region. Further studies revealed its broad ecological distribution, as it is also found in association with the roots of gramineous plants like rice, maize, sugarcane and sorghum $[5,6]$. This species is phylogenetically closer to Azospirillum irakense and Rhodospirillum centenum (also known as Rhodocista centenaria) than to A. brasilense. Unlike the latter, $A$. amazonense can use sucrose as a sole carbon source and is better adapted to acid environments [6].

In order to access the valuable information that genomic sequences can provide on the physiology of azospirilla, there have been independent efforts by research groups in sequencing their genomes. Currently, the genomes of three members of the Azospirillum-R. centenum group are available: Azospirillum sp. B510 [7], A. brasilense Sp245 [8] and $R$. centenum SW [9]. Although
C Biomed Central

() 2011 Sant'Anna et al; licensee BioMed Central Ltd. This is an Open Access article distributed under the terms of the Creative Commons Attribution License (http://creativecommons.org/licenses/by/2.0), which permits unrestricted use, distribution, and reproduction in any medium, provided the original work is properly cited. 
many years have passed since the discovery of $A$. amazonense, there is scarce information about this species. Nevertheless, a recent study under greenhouse conditions showed that especially $A$. amazonense Y2 (wildtype strain) contributed to the growth of rice plants by means of biological nitrogen fixation [10], showing its potential for use as an agricultural inoculant. Therefore, the objective of our study was to sequence the $A$. amazonense Y2 genome and to analyze specific regions that could exert fundamental roles in its survival in the soil and in its ability to promote plant growth.

\section{Results and Discussion}

\section{General features of the A. amazonense draft genome database}

The A. amazonense Y2 presents four replicons with the following estimated sizes: $2.7 \mathrm{Mbp}, 2.2 \mathrm{Mbp}, 1.7 \mathrm{Mbp}$ and $0.75 \mathrm{Mbp}$ [11] The genomic $\mathrm{G}+\mathrm{C}$ content of $A$. amazonense $\mathrm{Y} 2$ is $66.89 \%$. The draft genome sequence consists of 7.044 .835 bp divided in 1617 contigs. The average gene length is 1080. Currently, there are 3319 predicted CDS, where 2299 have sequence similarity to known genes, 501 are homologs to genes of unknown function and 519 are hypothetical genes exclusive to $A$. amazonense.

\section{Taxonomic features of A. amazonense}

In this study, a phylogenetic tree was constructed using the $16 \mathrm{~S}$ rDNA sequences from microorganisms belonging to the orders Rhodospirillales and Rhizobiales (Figure 1). The resulting phylogenetic tree clearly shows a split between these orders. The outermost clade containing all the Azospirillum species divides in two main subclades: one containing A. amazonense, A. irakense, Rhodocista pekingensis and $R$. centenum, and another containing the other Azospirillum species. This result is in agreement with previous studies, showing the close evolutionary relationship between $A$. amazonense and $R$. centenum [12-14], and is also supported by the greater number of $A$. amazonense genes (22\%) with best BLAST hits (KEGG Database) to $R$. centenum genes.

Another relevant feature of the $16 \mathrm{~S}$ rDNA phylogenetic reconstruction is that $R$. centenum does not cluster with other Rhodospirillum species, suggesting that the genus nomenclature of $R$. centenum is not appropriate, as has been pointed out by previous publications $[13,15]$.

\section{Carbon metabolism}

Azospirilla display versatile carbon metabolism in order to support their lives in the soil. A. amazonense is capable of growing on various disaccharides, hexoses and pentoses and a previous study suggested that A. amazonense is able to catabolize carbohydrates exclusively through the Entner-Doudoroff pathway (ED pathway)
[16]. The genes encoding the key enzymes of this pathway, 6-phosphogluconate dehydratase and 2-dehydro-3deoxy-phosphogluconate aldolase (KDPG aldolase) (Additional file 1), were found in the A. amazonense genome and seem to be organized as an operon. This same study also suggested that the glycolysis pathway (Embden-Meyerhof-Parnas pathway) was inoperative in A. amazonense, because no activity of 6-phosphofructokinase and fructose bisphosphate aldolase was detected in crude extracts [16]. However, predicted genes encoding those enzymes were found in the $A$. amazonense genome (Additional file 1). Therefore, although the genomic approach indicates that most probably $A$. amazonense is also able to consume carbohydrates via glycolysis, this catabolic feature should be experimentally retested.

As stated previously, one of the main differences between $A$. amazonense and $A$. brasilense is that $A$. amazonense is capable of consuming sucrose as the sole carbon source [6]. In the genome of $A$. amazonense, a predicted gene that codes for a putative $\alpha$-glucosidase was identified (Additional file 1). This enzyme converts sucrose to glucose and fructose, substrates that can be promptly consumed by catabolic pathways.

The $A$. amazonense genome also harbors homologs of the genes salB and salA of $A$. irakense (Additional file $1)$. These genes encode $\beta$-glucosidases, enzymes implicated in the acquisition of glucose by means of the hydrolysis of aryl- $\beta$-glucosides, such as salicin [17].

Bacteria of the genus Azospirillum produce high levels of poly- $\beta$-hydroxybutyrate (PHB), the energy and carbon storage source utilized under nutritional stress conditions [2,18]. The essential genes for PHB biosynthesis are present in the $A$. amazonense genome: phbA ( $\beta$ ketothiolase), $p h b B$ (aceto acetyl coenzyme A reductase) and phbC (PHB synthase) (Additional file 1). Furthermore, the phaZ gene that encodes a PHB depolymerase (Additional file 1), the first enzyme of the PHB degradation pathway, was also found in its genome.

One of the most surprising features of the A. amazonense genome is the presence of a gene cluster implicated in carbon fixation (the Calvin-Benson-Basham cycle) (Figure 2 and Additional file 1). The main genes of this cluster are the genes $c b b L$ and $c b b S$, and they encode, respectively, the large and small subunits of ribulose-1,5-bisphosphate carboxylase (RubisCO). This enzyme is responsible for the incorporation of carbon dioxide in a molecule of ribulose-1,5-bisphosphate, generating two molecules of 3-phosphoglycerate, which can subsequently be used in biosynthetic pathways. A phylogenetic analysis of the concatenated RubisCO small and large subunits of $A$. amazonense revealed that they belong to the Form IC of RubisCOs (Figure 3 ). This type of enzyme is commonly found in $\alpha$ - 


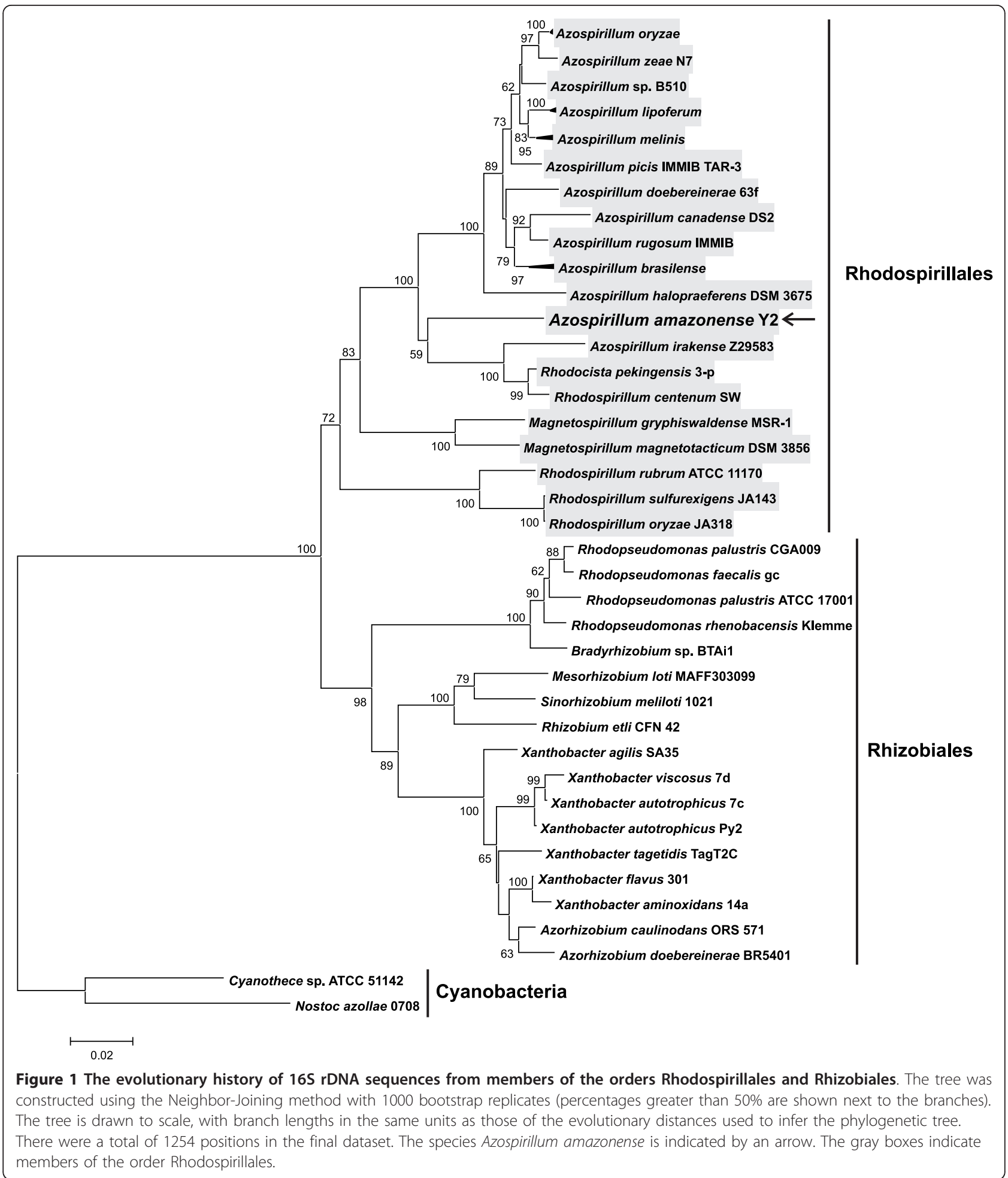

Proteobacteria and it is adapted to environments with medium to high $\mathrm{CO}_{2}$ and the presence of $\mathrm{O}_{2}$ (in general, RubisCOs also have affinity to $\mathrm{O}_{2}$ and high levels of this molecule can inhibit $\mathrm{CO}_{2}$ fixation) [19]. So far, there have been no reports showing that $A$. amazonense has autotrophic behavior. However, from the Azospirillum group, at least $R$. centenum and A. lipoferum are known to be capable of growing autotrophically by means of RubisCO $[9,20]$, unlike Azospirillum sp. B510 and A. brasilense Sp245, which do not 


\section{CARBON FIXATION-RELATED GENES}

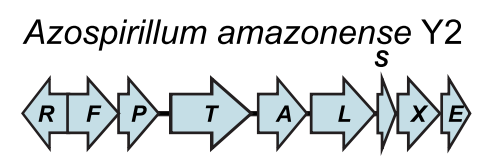

Rhodospirillum centenum SW

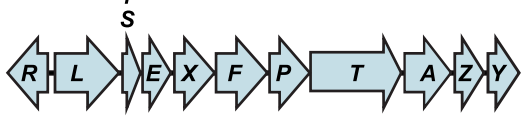

Bradyrhizobium sp. BTAi1

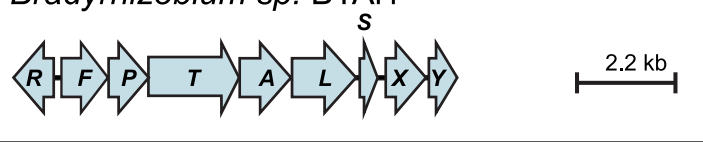

Figure 2 Organization of the carbon fixation gene cluster across different species. Arrows represent genes and their respective direction of transcription.

contain Form I or II of RubisCOs ("true" RubisCOs) encoded in their genomes.

The RubisCO phylogenetic reconstruction also indicated the close relationship of the A. amazonense enzyme with those from members of the family Bradyrhizobiaceae (order Rhizobiales) (Figure 3), namely Rhodopseudomonas palustris and Bradyrhizobium spp. In fact, the genetic organization of the carbon-fixation cluster of A. amazonense resembles that found in Bradyrhizobium sp. BTAi1, contrasting with the genetic organization of $R$. centenum. These incongruities, i.e. the genetic organization and phylogenetic relationship closer to Bradyrhizobiaceae members than to $R$. centenum, suggests that horizontal gene transfer may be an important driving force in the evolution and dispersion of RubisCOs in Proteobacteria.

\section{Nitrogen metabolism}

Azospirillum species are able to utilize distinct nitrogen sources, including ammonia, nitrate, nitrite, dinitrogen and amino acids [3,21]. The $A$. amazonense species has several genes implicated in nitrogen metabolism, which encode transporters, enzymes and regulatory proteins (Additional file 1).

Ammonia is the central compound of nitrogen metabolism and the preferred nitrogen source of many microorganisms. In general, nitrogen sources other than ammonia are converted into it to be assimilated [22]. The $A$. amazonense genome contains genes that are implicated in this conversion of alternative nitrogen sources, like nitrate/nitrite, urea and dinitrogen (Additional file 1). Once available, ammonia can be incorporated into the metabolism by the glutamine synthetase (GS)/glutamine:oxoglutarate aminotransferase (GOGAT) pathway, the genes for which are also encoded in the $A$. amazonense genome (Additional file $1)$.

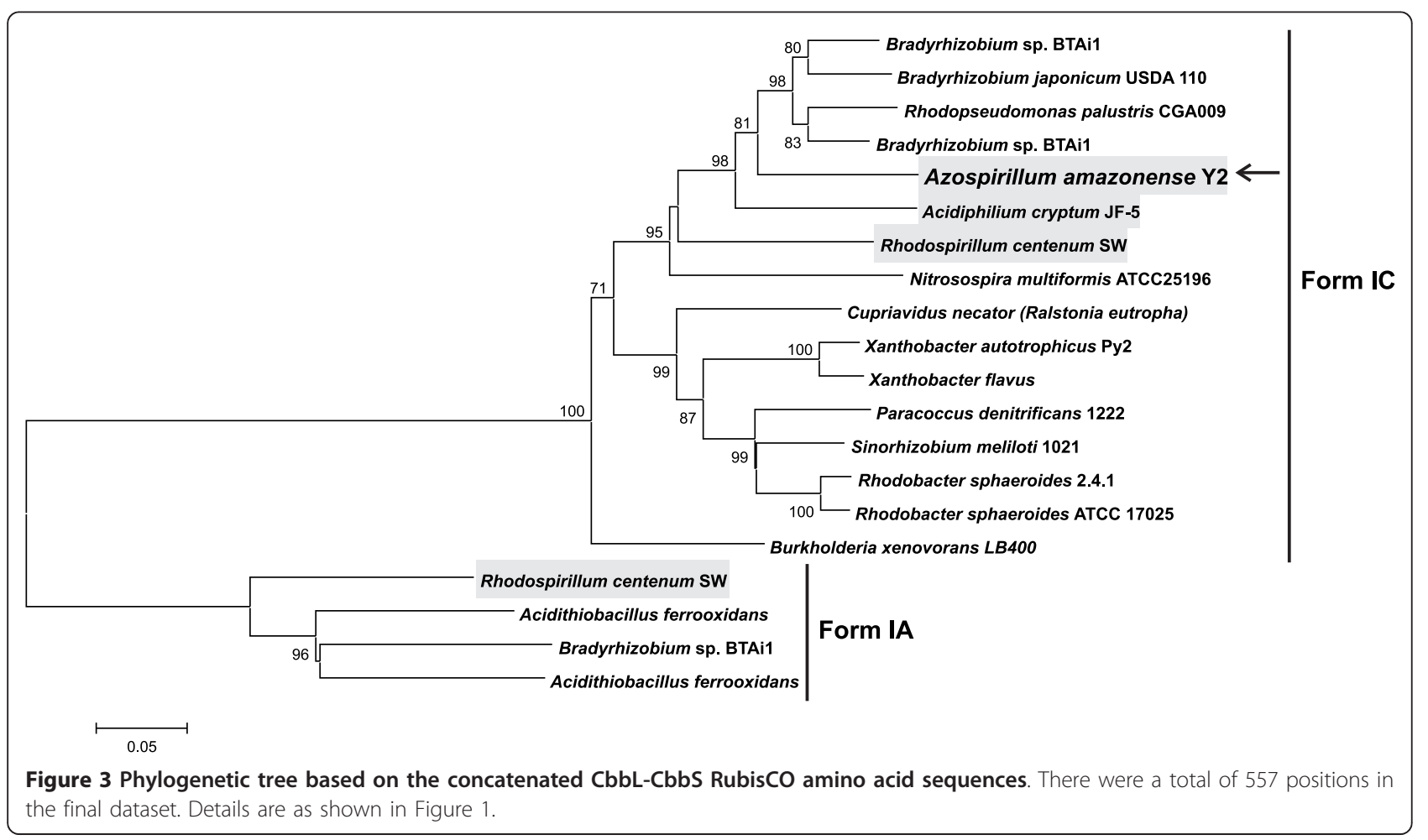


Overall, the conversion of nitrogen compounds to ammonia expends some energy and, therefore, the metabolic pathways implicated in this process are strictly regulated to minimize energy waste. The central regulators of nitrogen metabolism are the PII proteins [22,23]. Three PII homolog genes $(g \ln B, g \ln K$ and $g \ln K 2)$ were found in the $A$. amazonense genome (Additional file 1). The $g \ln K$ gene and the $g \ln B$ gene have ortholog counterparts in Azospirillum sp. B510, A. brasilense Sp245 and $R$. centenum. The $g \ln K$ gene is upstream of the aat gene (aminotransferase) and the $\operatorname{gln} B$ is upstream of the $g \ln A$ gene (glutamine synthetase) [24]. The third gene, $g \ln K 2$, which is located downstream of the $a m t B$ gene, is absent in A. brasilense Sp245, Azospirillum sp. B510 and $R$. centenum, although this genetic association is frequently found in diverse prokaryotes [25].

The PII protein interactions with transporters, transcription factors and regulatory enzymes are well-established in the literature (for a review, see $[22,23]$ ) and the potential interaction targets found in the $A$. amazonense genome will be briefly discussed. One putative target is the $g \ln D$ gene that codes for an uridilyl-transferase, an enzyme that uridylylates the PII proteins under nitrogen-limiting conditions [23]. Other potential targets found in the $A$. amazonense genome are two ammonium transporters, encoded by the $a m t B$ genes, which in the presence of high nitrogen levels are inhibited by PII proteins [26]. The adenylyltransferase enzyme (encoded by the $g \ln E$ gene, Additional file 1) which regulates glutamine synthetase via covalent modifications [27] could also interact with PII proteins [28].

The analysis of the $A$. amazonense genome revealed the presence of the NtrBC and NifA systems (Additional file 1), which are PII-regulated signal transduction systems responsible for the coordination of genes implicated in the scavenging of alternative nitrogen sources [23]. Both NtrC and NifA rely on the presence of the sigma $\mathrm{N}$ factor (also known as RpoN, or sigma 54) to activate the transcription of specific genes [29], which is also present in the $A$. amazonense genome (Additional file 1).

One of the main characteristics of the Azospirillum species is that they are able to fix nitrogen, i.e. convert $\mathrm{N}_{2}$ to ammonia, by means of the nitrogenase enzyme complex. The main genes implicated in this process are known as nif genes, and they are highly conserved among nitrogen-fixing proteobacteria [30].

A preliminary BLAST analysis showed that the $A$. amazonense nif genes exhibit high similarity with genes of some species of the order Rhizobiales (Additional file $1)$. Since these observations were unexpected, the phylogenetic history of nifH was reconstructed utilizing sequences from species of the orders Rhodospirillales and Rhizobiales. The resulting nifH tree (Figure 4) was clearly incongruent to the $16 \mathrm{~S}$ rDNA tree (Figure 1): in the nifH tree, $A$. amazonense and $A$. irakense grouped with Bradyrhizobium sp. BTAi1, Xanthobacter diazotrophicus and Azorhizobium caulinodans, instead of grouping with other Azospirillum species.

The genetic organization of the nif genes between the Rhodospirillales and Rhizobiales bacteria is somewhat homogeneous (Figure 5). As demonstrated in Figure 5, some features of the nif cluster of $A$. amazonense are exclusively similar to the homolog cluster of the species Bradyrhizobium sp. BTAi1, such as the presence of three conserved hypothetical genes that are indicated by the numbers 2, 5 and 6. On the other hand, Azospirillum sp. B510 and A. brasilense have the aer $C$ gene between the nifHDK and nifENX operons and the draG and $\operatorname{draT}$ genes in the upstream region of the nifH gene, features not shared with the nif cluster of $A$. amazonense. The genes draG and draT code for a posttranslational control system of the nitrogenase, which are not present in A. amazonense and $R$. centenum $[9,31]$.

The domain composition of the deduced NifE and NifU proteins is also evidence that the nitrogenase complex of $A$. amazonense is more distantly related to Azospirillum spp. (with the exception of $A$. irakense) than to some Rhizobiales species (i.e. those from the genus Bradyrhizobium, Xanthobacter and Azorhizobium). The NifE protein of $A$. amazonense (like the Bradyrhizobium, Xanthobacter and Azorhizobium proteins NifE) has a bacterioferritin-associated ferredoxin [2Fe-2S] binding domain (BFD), not present in the NifE protein from $A$. brasilense Sp245 and Azospirillum sp. B510, and $R$. palustris (Rhizobiales) (Additional file 2). Furthermore, its NifU protein is smaller than those of $A$. brasilense Sp245, Azospirillum sp. B510 and R. palustris CGA009 because it does not contain the BFD and an N-terminal NifU domain, which are present in the NifU protein of the latter species (Additional file 2).

Therefore, taken together, these results indicate that complex events occurred in the evolution of the nitrogenase system in these bacteria, for instance, horizontal gene transfers and/or gene duplication followed by differential gene loss, culminating in the current distribution of the nif genes among the members of these taxonomic orders.

Nitrogen fixation is a very energy-demanding process and it is not surprising that the nitrogenase system is elaborately regulated. In all diazotrophic species of the Proteobacteria examined so far, the transcriptional activator NifA and the sigma $\mathrm{N}$ alternative RNA polymerase-associated factor are the master regulators of nitrogen fixation genes [32]. Sequence motifs similar to the consensus region of sigma $\mathrm{N}$ and NifA binding sites are present upstream of the nifH gene, the homolog of 


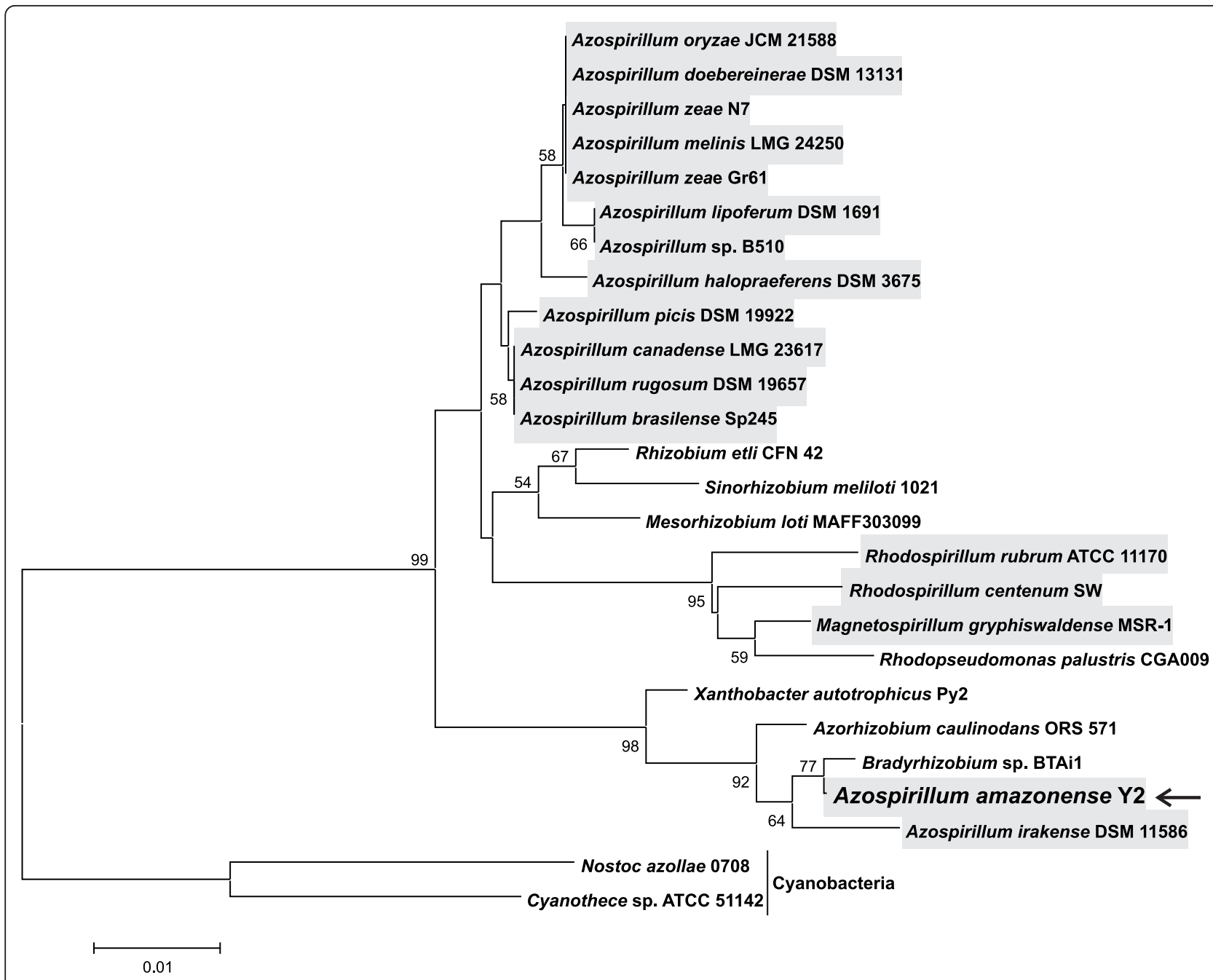

Figure 4 Phylogenetic tree based on the partial nifH gene from members of the orders Rhizobiales and Rhodospirillales. There were a total of 215 positions in the final dataset. Details are as shown in Figure 1.

"orf2" (indicated by the number 7 in Figure 5) of the orf2nifUSVorf4 cluster from A. brasilense [33] and the nifB gene (Additional file 3).

\section{Energy production and conversion for nitrogen fixation}

Nitrogen fixation demands the systematic action of different genes. The fix genes are essential for this process, and they encompass different functional categories. These genes were found in the $A$. amazonense genome divided into three main clusters, namely fix $A B C X$, fixLJfixK and fixNOQP-fixGHIS.

The fix $A B C X$ genes from $A$. amazonense, responsible for electron transfer to nitrogenase, are located downstream of the nifW gene (Figure 5). As seen in Figure 5, this genetic cluster is highly conserved among the analyzed species, and it is tightly associated with the nif cluster. Putative NifA and sigma $\mathrm{N}$ binding sites were found upstream of the operon fix $A B C X$ from $A$. amazonense (Additional file 3), indicating that these transcription factors could be key elements for the expression of this operon. This evidence is corroborated by reports showing that the operon fix $A B C X$ is regulated by the NifA protein in $A$. brasilense and Rhizobium spp. [34-36].

The A. amazonense genome also possesses a gene cluster including fixLJ and fixK. In symbiotic diazotrophs, the transcription of fix genes involves the oxygen-responsive FixLJ two-component system. The FixL protein, in the absence of oxygen, autophosphorylates and transfers the phosphate group to FixJ. Finally, the phosphorylated FixJ activates the expression of FixK, which activates the transcription of genes required for microaerobic growth [32].

Molecular nitrogen reduction requires high levels of energy under microaerobic conditions. The fixNOQP and fixGHIS genes encode membrane-bound 


\section{NITROGENASE COMPLEX GENES}

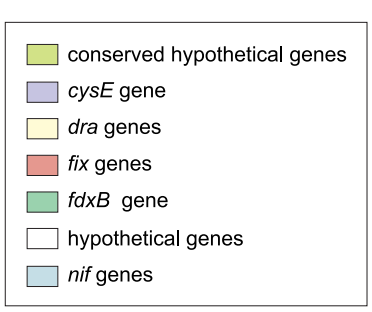

Azospirillum brasilense Sp245

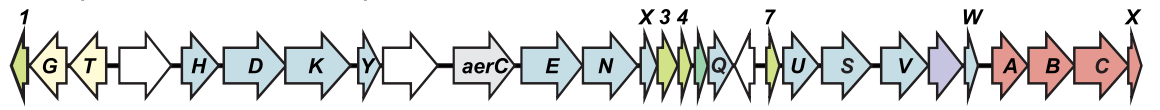

Azospirillum amazonense $\mathrm{Y} 2$

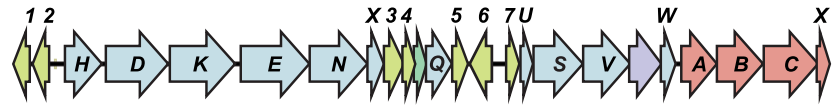

Azospirillum sp. B510

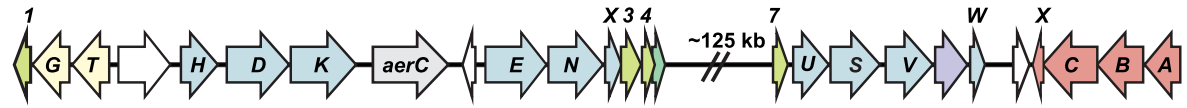

Bradyrhizobium sp. BTAi1

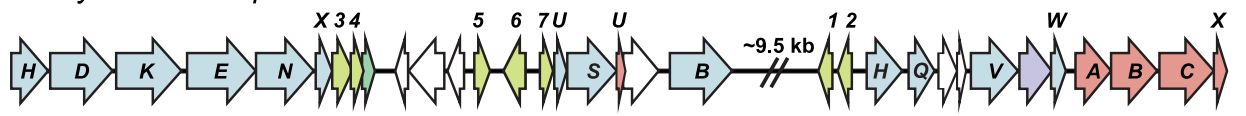

Rhodopseudomonas palustris CGA009

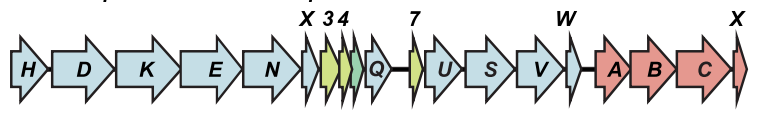

Figure 5 Organization of the nitrogen fixation gene cluster across different species. Arrows represent genes and their respective direction of transcription. Genes are colored as depicted in the upper box.

cytochrome c oxidase and the redox process-coupled cation pump, respectively, which are intimately implicated in respiration under microaerobic conditions, supplying energy for nitrogen fixation $[37,38]$. These clusters were found in tandem in the $A$. amazonense genome (Additional file 1), and they show identical organization in many diazotrophic $\alpha$-Proteobacteria, like $R$. centenum, A. brasilense Sp245, R. palustris and Bradyrhizobium spp.

Nitrogen fixation forms molecular hydrogen $\left(\mathrm{H}_{2}\right)$ as a byproduct. Therefore, diazotrophic bacteria have several hydrogenase systems that are responsible for oxidizing molecular hydrogen to recover part of the energy expended during nitrogenase activity. Genes encoding for an uptake NiFe hydrogenase (hupSL) were identified in A. amazonense (Figure 6). Furthermore, the accessory proteins required for maturation of the subunits [39,40], encoded by the hup and hyp genes, are situated downstream of the genes encoding hupSL (Figure 6). This organization resembles that found in members of the order Rhizobiales, where, in general, the hup and hyp genes are clustered (Figure 6), although their ordering is quite heterogeneous among the species. In contrast with this observation, comparisons with closely-related species showed that Azospirillum sp. B510 and A. brasilense
Sp245 have their hup and hyp genes scattered across the genome. Moreover, the bacteria $R$. centenum does not have the hydrogenase gene cluster.

An integrated model relating the components discussed in this section with nitrogen metabolism is depicted in Figure 7, taken into consideration the similarity of $A$. amazonense genes to those from other wellknown bacterial systems.

\section{Phytohormone production}

Species of the Azospirillum genus can positively influence plant growth and crop yield by the biosynthesis and secretion of indole-3-acetic acid (IAA) [2,41]. However, although $A$. amazonense strains are able to synthesize IAA [10], very little is known about the molecular mechanisms responsible for this process.

In $A$. brasilense, at least three pathways for IAA biosynthesis exist, two tryptophan-dependent pathways (indole-3-acetamide pathway (IAM) and indole-3-pyruvate pathway (IPyA)) and one tryptophan-independent pathway $[3,42]$. Similarly, the genome of Azospirillum sp. B510 contains genes responsible for the IAM pathway [7]. However, the $i a a M$, iaaH and ipdC genes, related to the IAM or IPyA pathways, were not located in the A. amazonense genome. Further analysis of the 


\section{HYDROGENASE COMPLEX GENES}

\section{Azospirillum amazonense Y2}

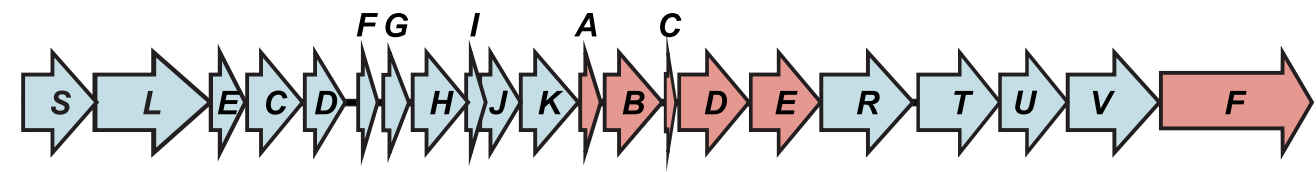

\section{Azorhizobium caulinodans}

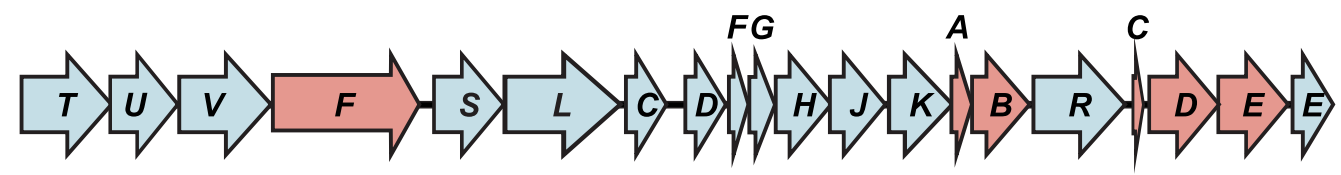

Rhodopseudomonas palustris CGA009

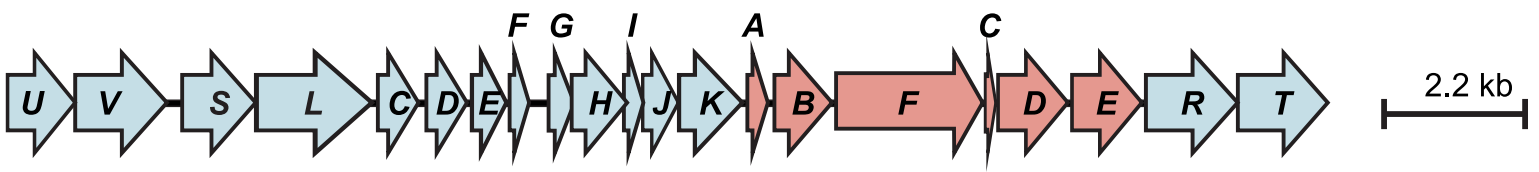

Figure 6 Organization of the hydrogenase gene cluster across different species from the orders Rhodospirillales and Rhizobiales. Arrows represent genes and their respective direction of transcription. hup genes are colored in red and hyp genes are colored in blue.

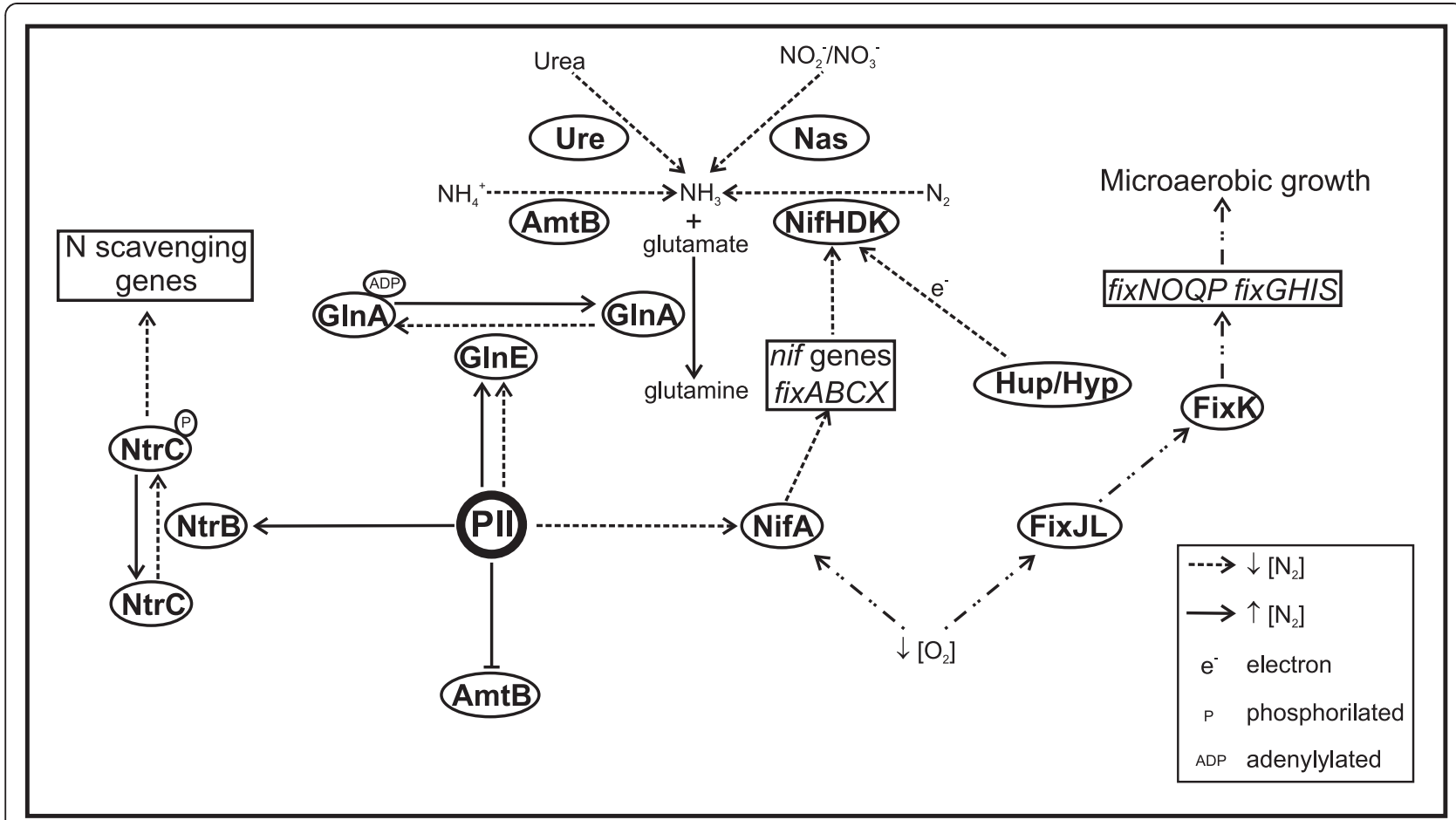

Figure 7 Integrated model correlating nitrogen metabolism and energy related-pathways for nitrogen fixation. The legend box indicates the correlation of each symbol with its respective meaning. 
genome sequence of $A$. amazonense revealed a gene encoding a protein with about $70 \%$ similarity to nitrilases from plant species, like Arabidopsis thaliana and Zea mays, which catalyze the conversion of indole 3acetonitrile to IAA $[43,44]$. Future studies may verify if this gene is implicated in IAA biosynthesis in $A$. amazonense.

\section{Quorum sensing and biofilm formation}

Quorum sensing is an intercellular signaling process implicated in the regulation of several traits of bacteria, notably antibiotic biosynthesis and biofilm formation. The archetype for quorum sensing regulation is the LuxIR system, which involves an acyl-homoserine lactone (AHL) synthase (LuxI homolog) and an AHLdependent transcriptional regulator (LuxR homolog) [45]. The quorum sensing phenomenon of Azospirillum species is strain-specific and seems to regulate functions linked to rhizosphere competence and adaptation to plant roots [46].

The acyl-homoserine lactone (AHL) biosynthesis ability of forty Azospirillum strains (including A. amazonense Y2) was previously investigated, and only four $A$. lipoferum strains seemed of being capable of synthesizing these compounds [47]. However, the genome analysis of $A$. amazonense revealed the presence of genes encoding for LuxI and LuxR homologs proteins (Additional file 1). Therefore, these results indicate that $A$. amazonense Y2 could synthesize AHLs and respond to its presence in the environment. The genome of $A$. amazonense also presents a Klebsiella pneumoniae ahlK homolog [48], a predicted gene that codes for a putative homoserine lactonase (Additional file 1) implicated in AHL degradation. Since bacterial plant pathogens rely on quorum sensing mechanisms to infect plants [45], a study of $A$. amazonense homoserine lactonase activity on the deleterious activities of these pathogens would be relevant.

Extracellular polysaccharides are loosely bound to the cell surface and play an important role in bacteriumplant interactions through the firm and irreversible anchoring of cells to the plant roots [3]. In the A. amazonense genome, two genes, noeJ (mannose-6-phosphate isomerase, Additional file 1) and noeL (GDP-mannose 4,6-dehydratase, Additional file 1), which are related to extracellular polysaccharide biosynthesis and biofilm formation, were also found [49].

\section{Chemotaxis/Motility}

Different species of Azospirillum attach to and colonize plant root surfaces and these processes depend on chemotaxis. Azospirilla exhibit chemotaxis towards sugars, amino acids, organic acids and root exudates [50]. This ability offers the bacteria the advantage of moving towards favorable nutrient conditions.

Genes encoding for the central signal transduction pathway for chemotaxis (che) are present in nearly all motile bacteria. This signal transduction system is composed of the conserved che $A W Y B R$ genes and a group of transmembrane chemoreceptors (known as MCPs or methyl-accepting proteins) that perceive environmental signals. Homologs of the cheAWYBR and MCP genes were identified in the $A$. amazonense genome (Additional file 1), and some che genes display similar organization to those found in the model organism Escherichia coli [51].

The A. amazonense Che1 gene cluster (cheAWYBR) revealed a conserved organization with the major chemotaxis gene cluster from A. brasilense Sp245, which modulates cell length and clumping behavior [52]. Apparently, this gene cluster also affects the production of exopolysaccharide and flocculation of A. brasilense. Other che-like genes (Che2 and Che3, Additional file 1) are present in the $A$. amazonense genome, probably encoding parallel signal transduction pathways that could have distinct functions, similar to those found in R. centenum [53,54].

It is also worth noting that genes encoding MCP domain proteins are spread throughout the A. amazonense genome. Some of them were classified accordingly to their similarities to $E$. coli chemoreceptors. All five types of $E$. coli MCP receptors were found in the $A$. amazonense genome (Additional file 1), and it is probable that some of them are related to cell motility by regulating the histidine kinase CheA that phosphorylates a response regulator, which in turn controls the rotational direction of the flagellar motor [55].

The flagellum is a key structure for the chemotactic response. In the $A$. amazonense genome, 39 flagellar genes were identified, and the majority of them are distributed among different gene clusters (Additional file 1 ). The reduced flagellar gene number in $A$. amazonense compared to those of the closely-related $A$. brasilense (79 annotated genes) and $R$. centenum (72 genes) species is in agreement with previous evidence indicating that A. amazonense synthesizes only the polar flagellum for swimming motility [56].

Homologs of the A. brasilense and $R$. centenum genes fliFHN-motA-flbD-flhAF-fleN [9,57] are present in $A$. amazonense (Additional file 1 ). The $A$. amazonense genome also contains other flagellar genes that display similar organization to those found in Azospirillum spp. and R. centenum (Figure 8).

Previous studies demonstrated that the transcription factor FlbD is related to the biosynthesis of lateral flagella in $A$. brasilense and the polar flagella in $R$. 


\section{FLAGELLAR GENE CLUSTER}

Azospirillum amazonense Y2
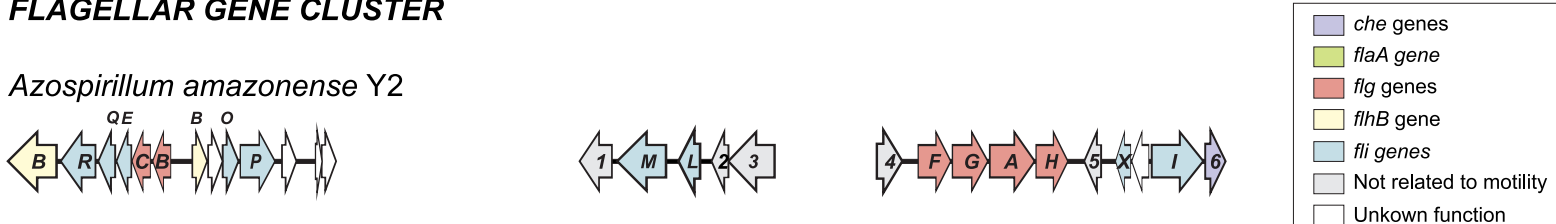

Rhodospirillum centenum SW

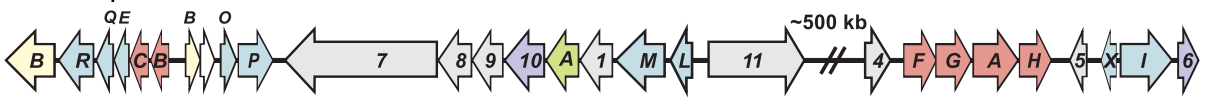

Azospirillum brasilense Sp245

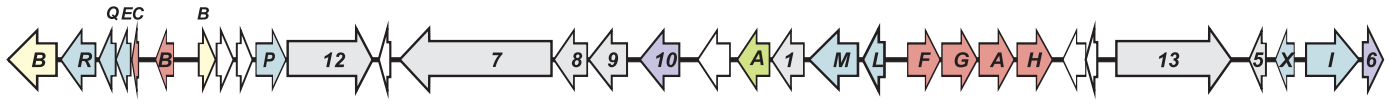

Azospirillum sp. B510

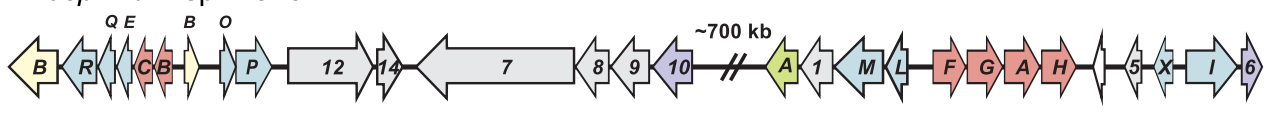

Figure 8 Organization of the flagellar gene cluster across different species. Arrows represent the genes and their respective direction of transcription. Genes are colored as depicted in the upper box. 1- ATPase involved in DNA repair, 2- glyoxalase/bleomycin resistance protein/ dioxygenase, 3- twin-arginine translocation pathway signal, 4- peptidylprolyl isomerase, 5- RNA polymerase-binding protein DksA, 6- chemotactic signal-response protein CheL, 7- tetratricopeptide TPR_2 (cell wall/envelope/membrane biosynthesis), 8- chemotaxis MotB protein, 9- PPE-repeat protein, 10- chemotaxis protein CheZ, a-flaA, 11- transglutaminase-like domain protein, 12- K+ transporter, 13- O-methyltransferase, 14- beta-lgH3/fasciclin.

centenum $[9,57]$. The presence of the $f l b D$ gene in the $A$. amazonense genome suggests that it could have a similar regulatory function as that found in $R$. centenum.

\section{Transport, antibiotics resistance and lantibiotic production}

Transport systems allow the uptake of nutrients and ions, excretion of end products of metabolism and communication between cells and the environment.

Several components of the cationic efflux pump, the ATP-Binding Cassette (ABC) transporter superfamily, the Major Facilitator Superfamily (MFS) and the TonBdependent transporters were identified in the A. amazonense genome.

TonB-dependent transport is a mechanism of active uptake across the outer membrane normally related to iron uptake, signal transduction and environmental perception [58,59]. A. amazonense has a high number of genes encoding TonB receptors (Additional file 1) when compared with other diazotrophs such as Azospirillum sp. B510 (9 annotated genes) and $R$. centenum SW (32 annotated genes). Homology analyses suggest that a set of putative TonB receptors for specific substrates like ferrioxamine, cobalamin (B12 vitamin) and heme are present in this bacterium.

Among the different families of transporters, only two occur ubiquitously in all kingdoms of life: the Major Facilitator Superfamily (MFS) and the ATP-Binding
Cassette $(\mathrm{ABC})$ superfamily, representing the largest and most distributed families of transmembrane proteins. MFS proteins are single polypeptide secondary carriers that utilize uniport, symport or antiport mechanisms to transport various small substrates [60]. The ABC transporter proteins utilize energy from adenosine triphosphate (ATP) hydrolysis to carry out the uptake of essential nutrients and/or the extrusion of toxic substances [61]. In the A. amazonense genome, several genes encoding for putative MFS and ABC transporters were identified, and they could be implicated in the transport of a wide range of putative substrates (Additional file 1).

Multidrug resistance (MDR) transporters increase drug excretion through an efflux pump, which expels a wide variety of toxic products from the cell, playing a central role in bacterial drug resistance. The MDR transporters belong to various transporter families [62]. In $E$. coli, the transport of diverse substrates out of the cell by the AcrAB-TolC efflux transporter can confer broad resistance to antibiotics [63]. The acrA and $a c r B$ genes normally form an operon whose transcription is regulated by the $a c r R$ gene product, and are found in the $A$. amazonense genome.

Putative drug resistance transporters of the QacA subfamily were found in the $A$. amazonense genome (Additional file 1), which could confer resistance to monovalent and bivalent cationic lipophilic antiseptics 
and disinfectants such as quaternary ammonium compounds [64].

Further analysis revealed that, in addition to the MDR transporters, a set of genes whose products could be related to specific antimicrobial resistance are present in the $A$. amazonense genome. Genes that code for penicillin, glyoxalase/bleomycin and tetracycline resistance are also present in the $A$. amazonense genome (Additional file 1). These findings corroborate the experimental data that shows that $A$. amazonense is tolerant to tetracycline and resistant to penicillin [6].

Lantibiotics are peptide-derived antibacterial substances produced by some bacteria, and are characterized by the presence of unusual amino acids like lanthionines and dehydrated amino acids [65]. Lantibiotic biosynthesis is frequently coregulated as part of a stress response when cells enter the late-log or stationary phase [66]. Most lantibiotics exert their antibiotic effect by either forming pores in the target cell membrane or by inhibiting cell wall synthesis, and many lantibiotics are bactericidal against a variety of Grampositive bacteria [67]. Genes related to lantibiotic synthesis were found in A. amazonense genome (Additional file 1).

The genes implicated in antibiotic resistance and in lantibiotic production are probably essential for successful establishment of this microorganism in the soil due to constant contact with niche competitors like fungi and other bacteria.

\section{Bacteriophytochrome}

The $A$. amazonense genome also harbors a bacteriophytochrome gene (Additional file 1). Similarly, Azospirillum sp. B510 has two genes that code for distinct types of bacteriophytochromes [7], and Bradyrhizobium sp. possesses three bacteriophytochrome genes [68]. In plants, phytochromes regulate the metabolic response to the light environment, but a variety of functions is found in other organisms [69]. The bacteriophytochromes in $R$. palustris regulate the biosynthesis of the photosynthetic apparatus [70], while in Deinococcus radiodurans and $R$. centenum, they regulate pigment biosynthesis [71]. Subsequent studies must be carried out to understand the role of the bacteriophytochrome in $A$. amazonense physiology.

\section{Conclusion}

In order to thrive, bacteria must adapt readily to environmental shifts by means of a wide variety of genotypic and phenotypic accommodations [72]. The rhizosphere is a good example of a dynamic environment, where fluctuations in its biological and chemical activities demand an appropriate response from its inhabitants. The species A. amazonense is a free-living plant growth- promoting rhizobacterium that is found in association with plants of agricultural importance. In this study, we identified a series of $A$. amazonense genes that could be essential for adaptation to the competitive environment of the rhizosphere. Its wide genetic repertoire confers a versatile metabolism (e.g. the ability to use different carbon and nitrogen sources), as well as different mechanisms of perceiving and exploring its surroundings. These characteristics could directly influence plant growth, for instance, by providing nitrogen and stimulatory compounds to plants. Another important finding was the greater similarity of some genes, e.g. nitrogenase and RubisCO genes, to genes of members of the order Rhizobiales than to genes from other Azospirillum species. This evidence illustrates the genetic plasticity of this species and indicates that evolutionary phenomena like horizontal gene transfer could be fundamental for adaptation to its environment.

The major impact of this work will be to guide subsequent studies for a better understanding of the potential of $A$. amazonense.

\section{Methods}

Bacterial strain, culture conditions, and DNA isolation

A. amazonense Y2 (ATCC 35120) was cultured in M79 medium $(10 \mathrm{~g} / \mathrm{L}$ of sucrose as a carbon source, $0.1 \mathrm{~g} / \mathrm{L}$ of $\mathrm{K}_{2} \mathrm{HPO}_{4}, 0.4 \mathrm{~g} / \mathrm{L}$ of $\mathrm{KH}_{2} \mathrm{PO}_{4}, 0.2 \mathrm{~g} / \mathrm{L}$ of $\mathrm{MgCl}_{2} .7 \mathrm{H}_{2} \mathrm{O}$, $0.1 \mathrm{~g} / \mathrm{L}$ of $\mathrm{NaCl}, 0.4 \mathrm{~g} / \mathrm{L}$ of yeast extract, $\mathrm{pH}$ 6.5) [73] with shaking at $150 \mathrm{rpm}$ and $35^{\circ} \mathrm{C}$ for 18 hours. Genomic DNA was isolated as described by Wilson [74]. The quality of the isolated genomic DNA was assessed by agarose gel electrophoresis.

\section{Genome sequencing, assembly, draft annotation}

Total genomic DNA was sequenced using the Roche 454 pyrosequencing platform following the manufacturer's instructions. The contigs were assembled using Newbler software version 2.3 with the default parameters. The estimated coverage of the genome was $35 x$. Some gaps present in the genes of interest were filled in by sequencing PCR fragments obtained from genomic DNA.

The annotation and analysis of the sequences were carried out using the System for Automated Bacterial Integrated Annotation (SABIA) [75]. This Whole Genome Shotgun project has been deposited at $\mathrm{DDBJ} /$ EMBL/GenBank under the accession AFBX00000000. The version described in this paper is the first version, AFBX01000000.

\section{Phylogenetic analysis}

Gene sequences were retrieved from GenBank. Most of the $16 \mathrm{~S}$ rDNA sequences were retrieved from the Ribosomal Database Project [http://rdp.cme.msu.edu/] $[76,77]$. The accession numbers of the sequences utilized 
in the phylogenetic reconstructions are listed in Additional file 4.

Multiple sequence alignments were performed using MUSCLE version 3.8 [78] and CLUSTALW (built into the MEGA 4 software) [79]. Phylogenetic trees were inferred using the neighbor-joining method (1000 bootstrap replicates) by the MEGA 4 software [80]. The evolutionary distances were computed using the Maximum Composite Likelihood method for the nucleotide sequences and the Jones-Taylor-Thornton (JTT) matrixbased method for the amino acid sequences. All positions containing gaps and missing data were eliminated from the datasets (complete deletion option).

\section{Additional material}

Additional file 1: Supplementary table 1. Genes of Azospirillum

amazonense described throughout the study.

Additional file 2: Supplementary Figure 1. Domain composition of the NifE and NifU proteins among bacteria from the orders Rhodospirillales and Rhizobiales. The oblong boxes represent protein domains which are colored according to the description in the legend.

Additional file 3: Supplementary table 2. Putative sigma N and NifA binding sites occurring upstream of some nif and fix genes.

Additional file 4: Supplementary table 3. Accession numbers of the sequences utilized in the phylogenetic reconstructions.

\begin{abstract}
Acknowledgements and Funding
We especially thank Dr. Augusto Schrank for the valuable effort that enabled the realization of this work. We also thank the Empresa Brasileira de Pesquisa Agropecuária - Centro Nacional de Pesquisa de Agrobiologia (EMBRAPACNPAB) for providing the A. amazonense Y2 strain. This work was supported by grants from the Brazilian National Research Council (CNPq) and the Fundação de Amparo à Pesquisa do Estado do Rio Grande do Sul (FAPERGS). FHS, RC, LAR and FMS received scholarships from Coordenação de Aperfeiçoamento de Pessoal de Nível Superior (CAPES).
\end{abstract}

\section{Author details}

'Centro de Biotecnologia, Universidade Federal do Rio Grande do Sul, Av. Bento Gonçalves, 9500, Campus do Vale, Porto Alegre, RS, Brazil. ${ }^{2}$ Laboratório Nacional de Computação Científica (LNCC), Petrópolis, RJ, Brazil.

${ }^{3}$ Departamento de Biologia Molecular e Biotecnologia - Centro de Biotecnologia, Universidade Federal do Rio Grande do Sul, Av. Bento Gonçalves, 9500, Campus do Vale, RS, Brazil.

\section{Authors' contributions}

ISS and ATRV conceived of and coordinated the study. FHS and RC extracted the genomic DNA. LGPA carried out the draft genome sequencing and assembly. FHS, LGPA, RC, LAR, FMS, MRSM and ISS performed the draft genome annotation. FHS, MRSM and RC carried out the comparative analyses. FHS carried out the phylogenetic analyses and created the illustrations. FHS, RC, LAR, FMS, MRSM and ISS analyzed the results. FMS and LAR wrote some sections of the manuscript. FHS and ISS wrote the manuscript. All authors read and approved the final manuscript.

Received: 29 April 2011 Accepted: 12 August 2011

Published: 12 August 2011

\section{References}

1. Bashan Y, De-Bashan LE: How the plant growth-promoting bacterium Azospirillum promotes plant growth - a critical assessment. Adv Agron 2010, 108:77-136.
2. Bashan Y, Holguin G, De-Bashan LE: Azospirillum-plant relationships: physiological, molecular, agricultural, and environmental advances (1997-2003). Can J Microbiol 2004, 50:521-577.

3. Steenhoudt $\mathrm{O}$, Vanderleyden J: Azospirillum, a free-living nitrogen-fixing bacterium closely associated with grasses: genetic, biochemical and ecological aspects. FEMS Microbiol Rev 2000, 24:487-506.

4. Lavrinenko K, Chernousova E, Gridneva E, Dubinina G, Akimov V, Kuever J, Lysenko A, Grabovich M: Azospirillum thiophilum sp. nov., a novel diazotrophic bacterium isolated from a sulfide spring. Int I Syst Evol Microbiol 2010, 60:2832-2837.

5. Baldani Jl, Baldani VLD: History on the biological nitrogen fixation research in graminaceous plants: special emphasis on the Brazilian experience. An Acad Bras Ciênc 2005, 77:549-579.

6. Magalhães FMM, Baldani JI, Souto SM, Kuykendall JR, Döbereiner J: A new acid-tolerant Azospirillum species. An Acad Bras Ciênc 1983, 55:417-430.

7. Kaneko T, Minamisawa K, Isawa T, Nakatsukasa H, Mitsui H, Kawaharada Y, Nakamura Y, Watanabe A, Kawashima K, Ono A, Shimizu Y, Takahashi C, Minami C, Fujishiro T, Kohara M, Katoh M, Nakazaki N, Nakayama S, Yamada M, Tabata S, Sato S: Complete genomic structure of the cultivated rice endophyte Azospirillum sp. B510. DNA Res 2010, 17:37-50.

8. Azospirillum brasilense Sp245. [http://genome.ornl.gov/microbial/abra/ 19sep08/].

9. Lu YK, Marden J, Han M, Swingley WD, Mastrian SD, Chowdhury SR, Hao J, Helmy T, Kim S, Kurdoglu AA, Matthies HJ, Rollo D, Stothard P, Blankenship RE, Bauer CE, Touchman JW: Metabolic flexibility revealed in the genome of the cyst-forming alpha-1 proteobacterium Rhodospirillum centenum. BMC genomics 2010, 11:325.

10. Rodrigues EP, Rodrigues LS, de Oliveira ALM, Baldani VLD, Teixeira KRS, Urquiaga S, Reis VM: Azospirillum amazonense inoculation: effects on growth, yield and $\mathrm{N}_{2}$ fixation of rice (Oryza sativa L.). Plant Soil 2008, 302:249-261.

11. Martin-Didonet CC, Chubatsu LS, Souza EM, Kleina M, Rego FG, Rigo LU, Yates MG, Pedrosa FO: Genome structure of the genus Azospirillum. J Bacteriol 2000, 182:4113-4116.

12. Stoffels M, Castellanos T, Hartmann A: Design and application of new $16 \mathrm{~S}$ rRNA-targeted oligonucleotide probes for the Azospirillum-SkermanellaRhodocista-cluster. Syst Appl Microbiol 2001, 24:83-97.

13. Fani R, Bandi C, Bazzicalupo M, Ceccherini MT, Fancelli S, Gallori E, Gerace L, Grifoni A, Miclaus N, Damiani G: Phylogeny of the genus Azospirillum based on 16S rDNA sequence. FEMS Microbiol Lett 1995, 129:195-200.

14. Zhang D, Yang H, Zhang W, Huang Z, Liu SJ: Rhodocista pekingensis sp. nov., a cyst-forming phototrophic bacterium from a municipal wastewater treatment plant. Int I Syst Evol Microbiol 2003, 53:1111-1114.

15. Kawasaki H, Hoshino Y, Kuraishi $H$, Yamasato K: Rhodocista centenaria gen. nov., sp. nov., a cyst-forming anoxygenic photosynthetic bacterium and its phylogenetic position in the Proteobacteria alpha group. $J$ Gen Appl Microbiol 1992, 38:541-551.

16. Martínez-Drets G, Fabiano E, Cardona A: Carbohydrate catabolism in Azospirillum amazonense. Appl Environ Microbiol 1985, 50:183-185.

17. Faure D, Desair J, Keijers V, Bekri MA, Proost P, Henrissat B, Vanderleyden J: Growth of Azospirillum irakense $\mathrm{KBC1}$ on the aryl beta-glucoside salicin requires either salA or salB. J Bacteriol 1999, 181:3003-3009.

18. Kadouri D, Jurkevitch E, Okon Y: Involvement of the reserve material polybeta-hydroxybutyrate in Azospirillum brasilense stress endurance and root colonization. Appl Environ Microbiol 2003, 69:3244-3250.

19. Badger MR, Bek EJ: Multiple Rubisco forms in proteobacteria: their functional significance in relation to $\mathrm{CO} 2$ acquisition by the CBB cycle. $J$ Exp Bot 2008, 59:1525-1541.

20. Hartmann A, Baldani Jl: The genus Azospirillum. In The Prokaryotes. Edited by: Dworkin M, Falkow S, Rosenberg E, Schleifer KH, Stackebrandt E. Springer New York; 2006:115-140.

21. Hartmann A, Zimmer W: Physiology of Azospirillum. In Azospirillum/Plant Associations. Edited by: Okon Y. Boca Raton: CRC Press; 1994:15-39.

22. Leigh JA, Dodsworth JA: Nitrogen regulation in bacteria and archaea. Annu Rev Microbiol 2007, 61:349-377.

23. Arcondéguy T, Jack R, Merrick M: PII signal transduction proteins, pivotal players in microbial nitrogen control. Microbiol Mol Biol Rev 2001, 65:80-105.

24. Sant'Anna FH, Andrade DS, Trentini DB, Weber SS, Schrank IS: Tools for genetic manipulation of the plant growth-promoting bacterium Azospirillum amazonense. BMC Microbiol 2011, 11:107. 
25. Sant'Anna FH, Trentini DB, de Souto Weber S, Cecagno R, da Silva SC, Schrank IS: The PII superfamily revised: a novel group and evolutionary insights. J Mol Evol 2009, 68:322-336.

26. Javelle A, Merrick M: Complex formation between AmtB and GlnK: an ancestral role in prokaryotic nitrogen control. Biochem Soc Trans 2005, 33:170-172.

27. Van Dommelen A, Spaepen S, Vanderleyden J: Identification of the glutamine synthetase adenylyltransferase of Azospirillum brasilense. Res Microbiol 2009, 160:205-212.

28. Atkinson MR, Ninfa AJ: Characterization of the GlnK protein of Escherichia coli. Mol Microbiol 1999, 32:301-313.

29. Shingler $V$ : Signal sensory systems that impact $\sigma(54)$-dependent transcription. FEMS Microbiol Rev 2011, 35:425-440.

30. Raymond J, Siefert JL, Staples CR, Blankenship RE: The natural history of nitrogen fixation. Mol Biol Evol 2004, 21:541-554.

31. Fu HA, Hartmann A, Lowery RG, Fitzmaurice WP, Roberts GP, Burris RH: Posttranslational regulatory system for nitrogenase activity in Azospirillum spp. J Bacteriol 1989, 171:4679-4685.

32. Dixon R, Kahn D: Genetic regulation of biological nitrogen fixation. Nat Rev Microbiol 2004, 2:621-631.

33. Frazzon J, Schrank IS: Sequencing and complementation analysis of the nifUSV genes from Azospirillum brasilense. FEMS Microbiol Lett 1998, 159:151-158.

34. David M, Daveran ML, Batut J, Dedieu A, Domergue O, Ghai J, Hertig C, Boistard P, Kahn D: Cascade regulation of nif gene expression in Rhizobium meliloti. Cell 1988, 54:671-683.

35. Miller SH, Elliot RM, Sullivan JT, Ronson CW: Host-specific regulation of symbiotic nitrogen fixation in Rhizobium leguminosarum biovar trifolii. Microbiology 2007, 153:3184-3195.

36. Sperotto RA, Gross J, Vedoy C, Passaglia LM, Schrank IS: The electron transfer flavoprotein fix $A B C X$ gene products from Azospirillum brasilense show a NifA-dependent promoter regulation. Curr Microbiol 2004, 49:267-273.

37. Preisig O, Anthamatten D, Hennecke H: Genes for a microaerobically induced oxidase complex in Bradyrhizobium japonicum are essential for a nitrogen-fixing endosymbiosis. Proc Natl Acad Sci USA 1993, 90:3309-3313.

38. Preisig O, Zufferey R, Hennecke $H$ : The Bradyrhizobium japonicum fixGHIS genes are required for the formation of the high-affinity cbb3-type cytochrome oxidase. Arch Microbiol 1996, 165:297-305.

39. Casalot L, Rousset M: Maturation of the [NiFe] hydrogenases. Trends Microbiol 2001, 9:228-237.

40. Manyani H, Rey L, Palacios JM, Imperial J, Ruiz-Argüeso T: Gene products of the hupGHIJ operon are involved in maturation of the iron-sulfur subunit of the [NiFe] hydrogenase from Rhizobium leguminosarum bv. viciae. J Bacteriol 2005, 187:7018-7026.

41. Malhotra M, Srivastava S: An ipdC gene knock-out of Azospirillum brasilense strain SM and its implications on indole-3-acetic acid biosynthesis and plant growth promotion. Antonie van Leeuwenhoek 2008, 93:425-433.

42. Spaepen S, Vanderleyden J, Remans R: Indole-3-acetic acid in microbial and microorganism-plant signaling. FEMS Microbiol Rev 2007, 31:425-448.

43. Kriechbaumer V, Park WJ, Piotrowski M, Meeley RB, Gierl A, Glawischnig E: Maize nitrilases have a dual role in auxin homeostasis and betacyanoalanine hydrolysis. J Exp Bot 2007, 58:4225-4233.

44. Vorwerk S, Biernacki S, Hillebrand H, Janzik I, Muller A, Weiler EW, Piotrowski M: Enzymatic characterization of the recombinant Arabidopsis thaliana nitrilase subfamily encoded by the NIT2/NIT1/NIT3-gene cluster. Planta 2001, 212:508-516.

45. Loh J, Pierson EA, Pierson L3, Stacey G, Chatterjee A: Quorum sensing in plant-associated bacteria. Curr Opin Plant Biol 2002, 5:285-290.

46. Boyer M, Bally R, Perrotto S, Chaintreuil C, Wisniewski-Dyé F: A quorumquenching approach to identify quorum-sensing-regulated functions in Azospirillum lipoferum. Res Microbiol 2008, 159:699-708.

47. Vial L, Cuny C, Gluchoff-Fiasson K, Comte G, Oger PM, Faure D, Dessaux Y, Bally R, Wisniewski-Dyé F: N-acyl-homoserine lactone-mediated quorumsensing in Azospirillum: an exception rather than a rule. FEMS Microbiol Ecol 2006, 58:155-168.

48. Park SY, Lee SJ, Oh TK, Oh JW, Koo BT, Yum DY, Lee JK: AhID, an Nacylhomoserine lactonase in Arthrobacter sp., and predicted homologues in other bacteria. Microbiology 2003, 149:1541-1550.
49. Lerner A, Castro-Sowinski S, Valverde A, Lerner H, Dror R, Okon Y, Burdman S: The Azospirillum brasilense Sp7 noeJ and noeL genes are involved in extracellular polysaccharide biosynthesis. Microbiology 2009, 155:4058-4068.

50. Zhulin IB, Armitage JP: Motility, chemokinesis, and methylationindependent chemotaxis in Azospirillum brasilense. J Bacteriol 1993, 175:952-958.

51. Wadhams GH, Armitage JP: Making sense of it all: bacterial chemotaxis. Nat Rev Mol Cell Biol 2004, 5:1024-1037.

52. Bible AN, Stephens BB, Ortega DR, Xie Z, Alexandre G: Function of a chemotaxis-like signal transduction pathway in modulating motility, cell clumping, and cell length in the alphaproteobacterium Azospirillum brasilense. J Bacteriol 2008, 190:6365-6375.

53. Berleman JE, Bauer CE: Involvement of a Che-like signal transduction cascade in regulating cyst cell development in Rhodospirillum centenum. Mol Microbiol 2005, 56:1457-1466.

54. Jiang ZY, Gest H, Bauer CE: Chemosensory and photosensory perception in purple photosynthetic bacteria utilize common signal transduction components. J Bacteriol 1997, 179:5720-5727.

55. Falke JJ, Bass RB, Butler SL, Chervitz SA, Danielson MA: The two-component signaling pathway of bacterial chemotaxis: a molecular view of signal transduction by receptors, kinases, and adaptation enzymes. Annu Rev Cell Dev Biol 1997, 13:457-512.

56. Moens S, Michiels K, Keijers V, Van Leuven F, Vanderleyden J: Cloning, sequencing, and phenotypic analysis of laf1, encoding the flagellin of the lateral flagella of Azospirillum brasilense Sp7. J Bacteriol 1995, 177:5419-5426.

57. Chang Y, Tang T, Li JL: Isolation of a flagellar operon in Azospirillum brasilense and functional analysis of FlbD. Res Microbiol 2007, 158:521-528.

58. Koebnik R: TonB-dependent trans-envelope signalling: the exception or the rule? Trends Microbiol 2005, 13:343-347.

59. Noinaj N, Guillier M, Barnard TJ, Buchanan SK: TonB-dependent transporters: regulation, structure, and function. Annu Rev Microbiol 2010, 64:43-60.

60. Pao SS, Paulsen IT, Saier MH: Major facilitator superfamily. Microbiol Mol Biol Rev 1998, 62:1-34.

61. Jones PM, George AM: The ABC transporter structure and mechanism: perspectives on recent research. Cell Mol Life Sci 2004, 61:682-699.

62. Saier MH, Paulsen IT: Phylogeny of multidrug transporters. Semin Cell Dev Biol 2001, 12:205-213.

63. Li XZ, Nikaido H: Efflux-mediated drug resistance in bacteria: an update. Drugs 2009, 69:1555-1623.

64. Brown MH, Skurray RA: Staphylococcal multidrug efflux protein QacA. J Mol Microbiol Biotechnol 2001, 3:163-170.

65. Chatterjee C, Paul M, Xie L, van der Donk WA: Biosynthesis and mode of action of lantibiotics. Chem Rev 2005, 105:633-684.

66. Okuda Ki, Yanagihara S, Sugayama T, Zendo T, Nakayama J, Sonomoto K: Functional significance of the E-Loop, a novel motif conserved in the lantibiotic-immunity $A B C$ transport systems. J Bacteriol 2010, 192:2801-2808.

67. Cotter $P$, Hill C, Ross P: Bacteriocins: developing innate immunity for food. Nat Rev Microbiol 2005, 3:777-788.

68. Jaubert M, Vuillet L, Hannibal L, Adriano JM, Fardoux J, Bouyer P, Bonaldi K, Fleischman D, Giraud E, Vermeglio A: Control of peripheral lightharvesting complex synthesis by a bacteriophytochrome in the aerobic photosynthetic bacterium Bradyrhizobium strain BTAi1. J Bacteriol 2008, 190:5824-5831.

69. Rockwell NC, Su YS, Lagarias JC: Phytochrome structure and signaling mechanisms. Annu Rev Plant Biol 2006, 57:837-858.

70. Giraud E, Zappa S, Vuillet L, Adriano JM, Hannibal L, Fardoux J, Berthomieu C, Bouyer P, Pignol D, Verméglio A: A new type of bacteriophytochrome acts in tandem with a classical bacteriophytochrome to control the antennae synthesis in Rhodopseudomonas palustris. J Biol Chem 2005, 280:32389-32397.

71. Davis SJ, Vener AV, Vierstra RD: Bacteriophytochromes: phytochrome-like photoreceptors from nonphotosynthetic Eubacteria. Science 1999, 286:2517-2520.

72. Roszak DB, Colwell RR: Survival strategies of bacteria in the natural environment. Microbiol Rev 1987, 51:365-379. 
73. Fred EB, Waskman SA: Laboratory Manual of General Microbiology with Special Reference to the Microorganisms of the Soil New York: McGraw-Hill Book Company, Inc; 1928.

74. Wilson K: Preparation of genomic DNA from bacteria. In Current Protocols in Molecular Biology.. 1 edition. Edited by: Ausubel FM, Brent R, Kingston RE, Moore DD, Seidman JG, Smith JA, Struhl K. New York: Wiley; 1997:-2.

75. Almeida LGP, Paixão R, Souza RC, Costa GC, arrientos FJA, antos MT, Imeida DF, asconcelos ATR: A System for Automated Bacterial (genome) Integrated Annotation-SABIA. Bioinformatics 2004, 20:2832-2833.

76. Cole JR, Chai B, Farris RJ, Wang Q, Kulam-Syed-Mohideen AS, McGarrell DM, Bandela AM, Cardenas E, Garrity GM, Tiedje JM: The ribosomal database project (RDP-II): introducing myRDP space and quality controlled public data. Nucleic Acids Res 2007, 35:D169-D172.

77. Cole JR, Wang Q, Cardenas E, Fish J, Chai B, Farris RJ, Kulam-SyedMohideen AS, McGarrell DM, Marsh T, Garrity GM, Tiedje JM: The Ribosomal Database Project: improved alignments and new tools for rRNA analysis. Nucleic Acids Res 2009, 37:D141-D145.

78. Edgar RC: MUSCLE: multiple sequence alignment with high accuracy and high throughput. Nucleic Acids Res 2004, 32:1792-1797.

79. Thompson JD, Higgins DG, Gibson TJ: CLUSTAL W: improving the sensitivity of progressive multiple sequence alignment through sequence weighting, position-specific gap penalties and weight matrix choice. Nucleic Acids Res 1994, 22:4673-4680.

80. Tamura K, Dudley J, Nei M, Kumar S: MEGA4: molecular evolutionary fenetics analysis (MEGA) software version 4.0. Mol Biol Evol 2007, 24:1596-1599.

doi:10.1186/1471-2164-12-409

Cite this article as: Sant'Anna et al:: Genomic insights into the versatility of the plant growth-promoting bacterium Azospirillum amazonense. BMC Genomics 2011 12:409.

\section{Submit your next manuscript to BioMed Central and take full advantage of:}

- Convenient online submission

- Thorough peer review

- No space constraints or color figure charges

- Immediate publication on acceptance

- Inclusion in PubMed, CAS, Scopus and Google Scholar

- Research which is freely available for redistribution

Submit your manuscript at www.biomedcentral.com/submit 